Biogeosciences, 10, 4641-4652, 2013

www.biogeosciences.net/10/4641/2013/

doi:10.5194/bg-10-4641-2013

(C) Author(s) 2013. CC Attribution 3.0 License.

\title{
Distribution of methane in the Lena Delta and Buor-Khaya Bay, Russia
}

\begin{abstract}
I. Bussmann
Alfred Wegener Institute for Polar and Marine Research, Marine Station Helgoland, Kupromenade 201, 27498 Helgoland, Germany
\end{abstract}

Correspondence to: I. Bussmann (ingeborg.bussmann@awi.de)

Received: 1 October 2012 - Published in Biogeosciences Discuss.: 15 November 2012

Revised: 30 April 2013 - Accepted: 7 May 2013 - Published: 11 July 2013

\begin{abstract}
The Lena River is one of the largest Russian rivers draining into the Laptev Sea. The permafrost areas surrounding the Lena are predicted to thaw at increasing rates due to global temperature increases. With this thawing, large amounts of carbon - either organic or in the gaseous forms carbon dioxide and methane - will reach the waters of the Lena and the adjacent Buor-Khaya Bay (Laptev Sea). Methane concentrations and the isotopic signal of methane in the waters of the Lena Delta and estuary were monitored from 2008 to 2010. Creeks draining from permafrost soils produced hotspots for methane input into the river system (median concentration $1500 \mathrm{nM}$ ) compared with concentrations of $30-85 \mathrm{nM}$ observed in the main channels of the Lena. No microbial methane oxidation could be detected; thus diffusion is the main process of methane removal. We estimated that the riverine diffusive methane flux is $3-10$ times higher than the flux from surrounding terrestrial environment. To maintain the observed methane concentrations in the river, additional methane sources are necessary. The methane-rich creeks could be responsible for this input.

In the estuary of Buor-Khaya Bay, methane concentrations decreased to $26-33 \mathrm{nM}$. However, within the bay no consistent temporal and spatial pattern could be observed. The methane-rich waters of the river were not diluted with marine water because of a strong stratification of the water column. Thus, methane is released from the estuary and from the river mainly by diffusion into the atmosphere.
\end{abstract}

\section{Introduction}

The Arctic Ocean is an intercontinental sea surrounded by the land masses of Alaska, Canada, Greenland and Siberia/Russia. About $10 \%$ of global runoff flows into the large areas of shallow Arctic shelf seas (Lammers et al., 2001). Many Arctic rivers carry high concentrations of dissolved and particulate material. In addition, eroding coastlines also contribute to a strong terrestrial input (Dittmar and Kattner, 2003; Lantuit et al., 2011). The carbon gases $\mathrm{CO}_{2}$ and $\mathrm{CH}_{4}$ can comprise about half of the total carbon exported by an Arctic river and its tributaries (Striegl et al., 2012). During all seasons the Lena River is supersaturated in $\mathrm{CO}_{2}$ compared to the atmosphere resulting also in a significant $\mathrm{CO}_{2}$ supersaturation in the adjacent coastal sea (Semiletov et al., 2011, 2013).

Although most regions on earth have warmed over recent decades, warming in the Arctic progresses much faster than the global average, and, consequently, observed changes are more extreme (Symon et al., 2005; IPCC, 2007). One of the most obvious implications of the observed warming is that river runoff will change, respectively increase (Peterson et al., 2002). During 1964-2000 the discharge to the Arctic Ocean has increased by $5.6 \mathrm{~km}^{3} \mathrm{yr}^{-1}$, mostly due to a large increase from the Eurasian rivers (McClelland et al., 2006). Changes in precipitation, evaporation, and a variety of permafrost characteristics are the main drivers for the increase in annual river discharge (McClelland et al., 2012). Not only the river discharge will significantly change, due to permafrost and therefore large soil thawing, but also the terrestrial freshwater system is likely to change from a surfacewater-dominated system to a groundwater-dominated system 
(Frey and McClelland, 2009). Both increasing river runoff and decreasing permafrost extent are expected to increase dissolved inorganic carbon content of the important Arctic rivers (Tank et al., 2013). The disproportionate influence of rivers on the Arctic Ocean means that changes in the discharge or chemistry of Arctic rivers have potentially large implications for ocean physics, chemistry and biology (Holmes et al., 2012).

In the Arctic there are substantial stocks of carbon; however, there are also significant uncertainties associated with the magnitude of organic matter stocks contained in permafrost, and the storage of methane hydrates beneath both subterranean and submerged permafrost of the Arctic (McGuire et al., 2009). The Arctic is a substantial source of methane to the atmosphere (between 32 and $112 \mathrm{Tg} \mathrm{CH}_{4} \mathrm{yr}^{-1}$ ), primarily because of the large area of wetlands throughout the region (McGuire et al., 2009; Fisher et al., 2011). Also the carbon dioxide input will increase by the changes described above (Semiletov et al., 2013). Because methane is an efficient greenhouse gas, understanding methane sources and sinks is important for studying local processes and determining global methane budgets. However, methane release from the Arctic area, including gas hydrate and marine permafrost, is not yet included in the IPCC methane budget calculations.

The Lena River is the second-largest river $\left(530 \mathrm{~km}^{-3} \mathrm{yr}^{-1}\right)$ draining into the shallow Laptev Sea and further into the Arctic Ocean (Peterson et al., 2002). The methane cycle in the Laptev and East Siberian Sea (ESS) has been investigated intensively by Shakhova and Semiletov and co-workers. The rivers Indigirka and Kolyma transport significant amounts of methane into the East Siberian Sea (Shakhova et al., 2005), and even the atmospheric methane signal mirrored the strong methane import of this area (Shakhova and Semiletov, 2007). However, the influence of the Lena River on the methane budget of the ESS and Laptev Sea is not quite clear. Some previous studies have suggested that it plays a minor role (Semiletov et al., 2011), whereas others reported high methane concentrations in its estuary (Shakhova et al., 2010).

The aim of this study is to give a first estimate for the riverine input of methane into the estuary of the Lena Delta/Laptev Sea and to determine the further fate of this methane in the marine water via dilution, microbial consumption or diffusion into the atmosphere. Therefore we monitored the methane distribution and its isotopic composition in the Lena Delta in 2008-2010 and also tried to assess methane oxidation activity.

\section{Material and methods}

\subsection{Study site}

The Lena River is the second largest Arctic river and discharges $530 \mathrm{~km}^{3}$ fresh water annually (McClelland et al., 2012). Most of the water is discharged during end of May and beginning of June when the ice in the rivers breaks up, but the Laptev Sea is still covered by sea ice (Holmes et al., 2012). The main Lena River branches enter the Buor-Khaya Bay through the northern and eastern part of the delta: the Trofimovskaya Channel with 60-75\% of the Lena River water discharge and the Bykovskaya Channel with 20-25\%, while the Olenekskaya Channel with only $5-10 \%$ of water discharge flows westward (Charkin et al., 2011). The further distribution of the river water in Buor-Khaya Bay is mainly driven by the atmospheric systems of the cyclonic or anticyclonic Arctic circulation (Wegner et al., 2013; Heim et al., 2013).

Water samples were collected during three summer expeditions (9.8-14.8, 2008 (Boike et al., 2009); 14.8-23.8, 2009 (Wetterich et al., 2011) and 29.7-9.8, 2010) within the main channels (Trofimovskaya, Bykovskaya and Olenekskaya Channel) of the Lena River and Buor-Khaya Bay (Fig. 1a). Stations in the Bykovskaya and Olenekskaya Channel were identical (within $0.05^{\circ}$ ) in 2009 and 2010. Stations in Buor-Khaya Bay were only partly comparable between the years (Fig. 1b).

\subsection{Water sampling}

River water was sampled from the Puteyski 405 survey ship, via a Unite water sampler (Unite, Austria). Coastal water was sampled with Niskin bottles from the ship TB 0012 during 2010. For river water, additional parameters (temperature, salinity, oxygen, $\mathrm{pH}$ ) were obtained with a portable multiparameter probe (Multi 350i, WTW) on board. For coastal water these parameters were determined with a CTD probe (Eco 159, Sea and Sun) directly in the water. Water samples were collected from the surface $(1 \mathrm{~m})$, above and below the thermocline if applicable, and near the bottom (approx. $1 \mathrm{~m}$ above the ground).

Serum bottles $(120 \mathrm{~mL})$ were filled with thin silicon tubing from the water sampler. The bottles were flushed extensively with sample water (to ensure no contact with the atmosphere) and finally closed with butyl stoppers; excess water could escape via a needle in the stopper. Samples were poisoned with $0.01 \% \mathrm{HgCl}_{2}$. In the home laboratory, $20 \mathrm{~mL}$ of nitrogen were added to extract methane from the water phase, and excess water could escape via a needle. The volumes of the water and gas phases were calculated by differential weighing.

Water from creeks draining from permafrost soil was filled directly into $12 \mathrm{~mL}$ serum vials and analysed as described above. 


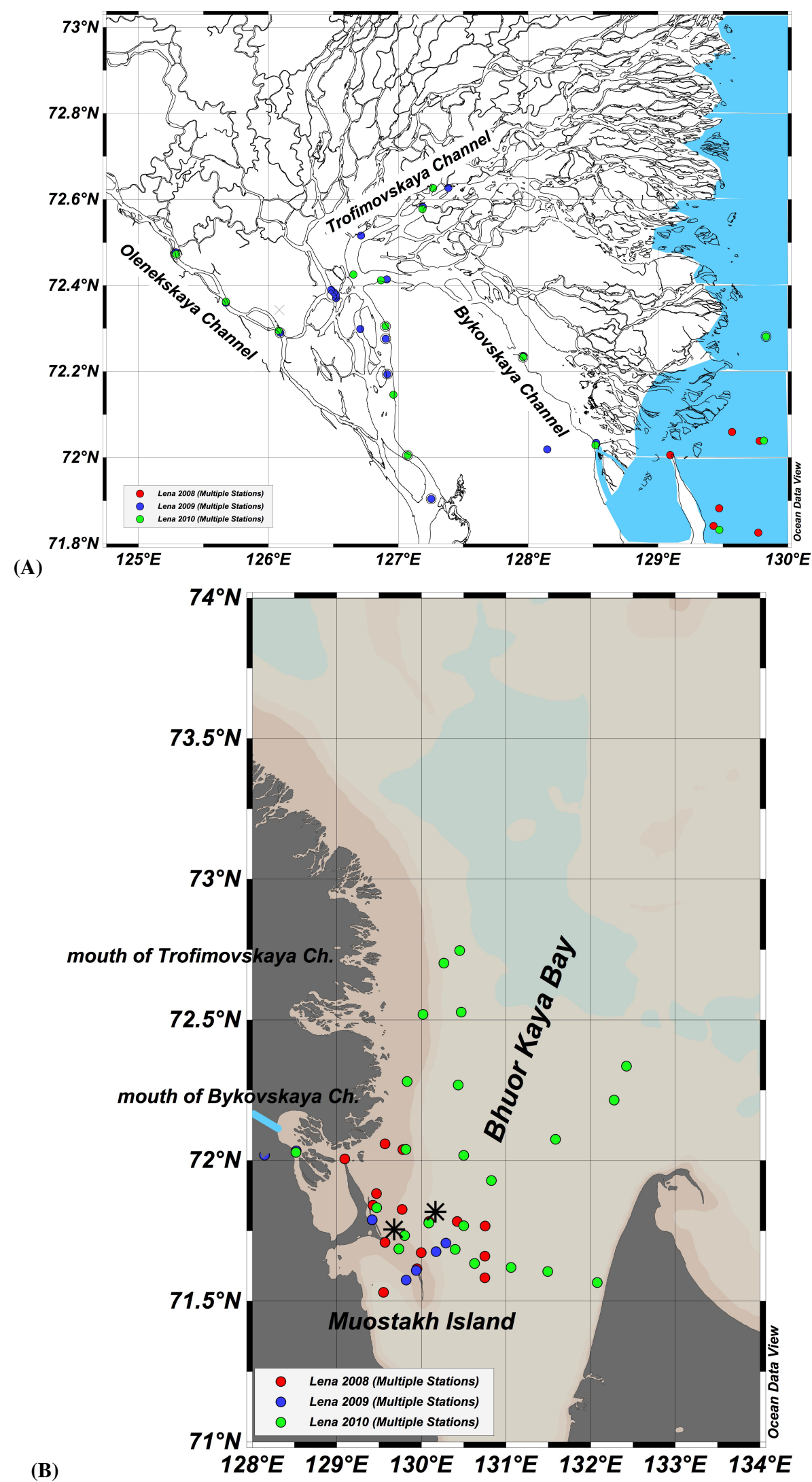

Fig. 1. Sampling stations in the years 2008 (red), 2009 (blue) and 2010 (green) within the Lena Delta and Buor-Khaya Bay. (A) shows the river stations, $(\mathbf{B})$ the estuarine stations. Asterisks indicate stations with special isotopic signature. 


\subsection{Gas analysis}

Headspace methane concentrations were analysed in the laboratory with a gas chromatograph (GC 2014, Shimadzu) equipped with a flame ionisation detector and a molecular sieve column (Hay Sep N, 80/100, Alltech). The temperatures of the oven, the injector and detector were $40^{\circ} \mathrm{C}$, $120^{\circ} \mathrm{C}$ and $160^{\circ} \mathrm{C}$, respectively. The carrier gas $\left(\mathrm{N}_{2}\right)$ flow

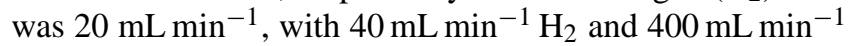
synthetic air. Gas standards (Air Liquide) with methane concentrations of 10 and $100 \mathrm{ppm}$ were used for calibration.

After measuring the methane concentration, the headspace was analysed for the isotopic composition of methane. Depending on the methane concentration of the headspace, 0.5 $2.5 \mathrm{~mL}$ of the headspace was transferred into an evacuated $20 \mathrm{ml}$ gas sampling tube. These data are only available for 2010.

The $\delta^{13} \mathrm{C}_{\mathrm{CH}_{4}}$ values were determined by a Finnigan DELTAplus XP mass spectrometer. The extracted gas was purged and trapped with a PreCon unit to pre-concentrate the sample. Reproducibility derived from duplicates was $0.1-$ $0.7 \%$, depending on the amount of methane. The isotope ratios are presented relative to the VPDB (Vienna Pee Dee Belemnite) standard using the conventional delta notation (Craig, 1957).

\subsection{Calculation of methane oxidation}

For the calculation of the fraction of methane oxidised, the maximum methane concentration of a sample group was set as fraction 1, and the other concentrations were related to this concentration accordingly. Starting from the data point with the maximum methane concentration and the corresponding $\delta^{13} \mathrm{C}$, the theoretical delta ${ }^{13} \mathrm{C}$ of a given methane fraction was calculated. A Rayleigh distillation model of the type discussed by Coleman et al. (1981), i.e.

$\delta^{13} \mathrm{C}_{\mathrm{CH}_{4}}=1000 \cdot(1 / \alpha-1) \cdot \ln f+\left(\delta^{13} \mathrm{C}_{\mathrm{CH}_{4}}\right)_{0}$,

was used to determine fraction $f$ of the methane remaining (thus, $1-f$ is the methane consumed by oxidation), where $\alpha$ is the kinetic isotope fractionation factor and $\left(\delta^{13} \mathrm{C}_{\mathrm{CH}_{4}}\right)_{0}$ is the starting stable isotopic composition. From the literature, fractionation factors for microbial methane oxidation range from 1.02 in fresh water (Bastviken et al., 2002) to 1.017 for Arctic marine water (Damm et al., 2007). When only diffusion is assumed, an $\alpha$ of 1.0009 is reported (Happell et al., 1995).

\subsection{Determination of the methane oxidation or production rate}

Simple incubation experiments were set up to determine the change of methane concentration over time. One set of samples $(n=2-3)$ were stopped at the beginning of the incubation, the other set after $24 \mathrm{~h}$ or $40 \mathrm{~h}$ incubation in the dark, near in situ temperature $\left(6-16^{\circ} \mathrm{C}\right)$. Incubation was stopped by the addition of $\mathrm{HgCl}_{2}(0.01 \%$ final concentration). In the home laboratory, the difference in methane concentrations was determined. Methane concentrations ranged from 300$400 \mathrm{nM}$.

\subsection{Calculation of the methane flux}

Gas exchange across an air-water interface can be described in general by the following function (Wanninkhof et al., 2009): $F=k \cdot\left(c_{\mathrm{m}}-c_{\mathrm{e}}\right)$, where $F$ is the rate of gas flux per unit area, $c_{\mathrm{m}}$ the methane concentration measured in surface water and $c_{\mathrm{e}}$ the atmospheric gas equilibrium concentration based on Wiesenburg and Guinasso (1979). The gas exchange coefficient, $k$, is a function of water surface agitation. However, in oceans and estuaries, $k$ in more determined by wind speed, while in rivers water velocity dominates (Alin et al., 2011). Therefore $k$ for river water was calculated according to the empirical Eq. (7) from Raymond et al. (2012):

$k_{600}=4725 \cdot(V \cdot S)^{0.86} \cdot Q^{-0.14} \cdot D^{0.66}$

with $V$ as stream velocity $\left(\mathrm{m} \mathrm{s}^{-1}\right), S$ as slope, $Q$ as discharge $\left(\mathrm{m}^{3} \mathrm{~s}^{-1}\right)$ and $D$ as depth (m). Data on stream discharge, velocity and depth were provided by Fedorova et al. (2013). The slope of the Lena in its delta was $1 \cdot 10^{-5}$. This slope is rather shallow, compared to the Yukon $\left(1 \cdot 10^{-4}\right)$; only the Amazonas is as shallow (Syvitski and Saito, 2007). For comparison with other studies, $k$ for methane can be converted to $k_{600}$ (value for $\mathrm{CO}_{2}$ at $20^{\circ} \mathrm{C}$ ) according to Striegl et al. (2012):

$k_{\mathrm{CH}_{4}} / k_{600}=\left(S c_{\mathrm{CH}_{4}} / S c_{\mathrm{CO}_{2}}\right)^{0.69}$.

Schmidt numbers $(S c)$ are determined by water temperature and salinity, according to Wanninkhof (1992).

In the estuary, the functions developed by Wanninkhof (1992) were used to calculate the flux of dissolved methane into the atmosphere:

$k=0.3 l \cdot u^{2} \cdot\left(S c_{\mathrm{CH}_{4}} / 660\right)^{-0.5}$

with $u$ as wind speed. In addition to our data on water temperatures, salinities and methane concentrations at transects 1 and 3, we used wind speeds of $2-4 \mathrm{~m} \mathrm{~s}^{-1}$ (www.aari.ru, data for Tiksi).

\section{Results}

\subsection{Hydrographic/oceanographic information}

For 2008 and 2009, only data from the surface and the bottom are available, whereas data for 2010 cover the whole water column in Buor-Khaya Bay.

In 2008, temperatures in the middle of Buor-Khaya Bay ranged between 13 and $15^{\circ} \mathrm{C}$ at the surface and $3-4{ }^{\circ} \mathrm{C}$ at 
the bottom. The corresponding salinities were around 1 at the surface and around 21 at the bottom. Otherwise, temperatures ranged from 10 to $18^{\circ} \mathrm{C}$ with salinities $<1$.

In 2009, the Lena River had an average temperature of $12^{\circ} \mathrm{C}$. Only one station was found to have brackish water (12 PSU and $2^{\circ} \mathrm{C}$ ).

In 2010, the main channels of the Lena River had an average temperature of $16^{\circ} \mathrm{C}$, only the Olenekskaya Channel was much warmer with $19^{\circ} \mathrm{C}$. No differences were observed between surface and bottom temperatures in the channels. In Buor-Khaya Bay a distinct stratification was observed (Fig. 2): cold, saline water was observed below a water depth of $12 \mathrm{~m}$, while at the surface the warmer Lena River water extended far to the northeast (Bussmann, 2011).

\subsection{Methane concentrations}

In a first spatial classification, the data were sorted into estuarine, riverine and creek water samples (Fig. 3). During the entire sampling time, no significant differences were found between surface and bottom water methane concentrations in the river as well as in the estuary. Thus surface and bottom water data are pooled in the following analyses.

Methane concentrations in the creeks draining from permafrost soil were extremely high $(914 \mathrm{nM}$ in 2009 and $1854 \mathrm{nM}$ in 2010 , median of $1505 \mathrm{nM}, n=7$, for all samples, Fig. 3). These creeks drain into the Lena River, but river concentrations were shown to be much lower with median concentrations of $30 \mathrm{nM}$ and $85 \mathrm{nM}$ in 2009 and 2010 respectively. The equilibrium concentration of methane at the respective temperature (and salinity) was around $3.2 \mathrm{nM}$; thus the river was $900 \%$ and $3000 \%$ oversaturated. A closer look at the three main channels revealed that significantly higher concentrations were always found in all sampling years in Olenekskaya Channel (median concentrations of 147 and $393 \mathrm{nM}$ in 2009 and 2010, respectively). The other channels however revealed distinct differences among the different years. While in 2009, the Bykovskaya Channel had a similar concentration as the Trofimovskaya Channel (median of $33 \mathrm{nM}$ versus $25 \mathrm{nM}$ ), in 2010, the Bykovskaya Channel methane concentrations were significantly lower than in the Trofimovskaya Channel (median $70 \mathrm{nM}$ versus $86 \mathrm{nM}$ ). For 2008 , no data on the river are available.

In the estuary, the median concentrations were $28 \mathrm{nM}$ in $2008,33 \mathrm{nM}$ in 2009 and $26 \mathrm{nM}$ in 2010 . In all years, methane concentrations showed a distinct intra-annual variability (Fig. 3). The equilibrium concentration of methane at the respective temperatures and salinities was around $3.4 \mathrm{nM}$; thus the estuary was $919 \%$ oversaturated.

However, in the different years we could not always sample the same stations. Thus for a better comparison we restricted the analysed area to $129-130.8^{\circ} \mathrm{E}$ and $71.5-72.1^{\circ} \mathrm{N}$, as "common area" which was sampled in all three years (Fig. 4). In 2008 methane-rich Lena surface water (up to $433 \mathrm{nM})$ with a low salinity $(<1)$ spread near the mouth of

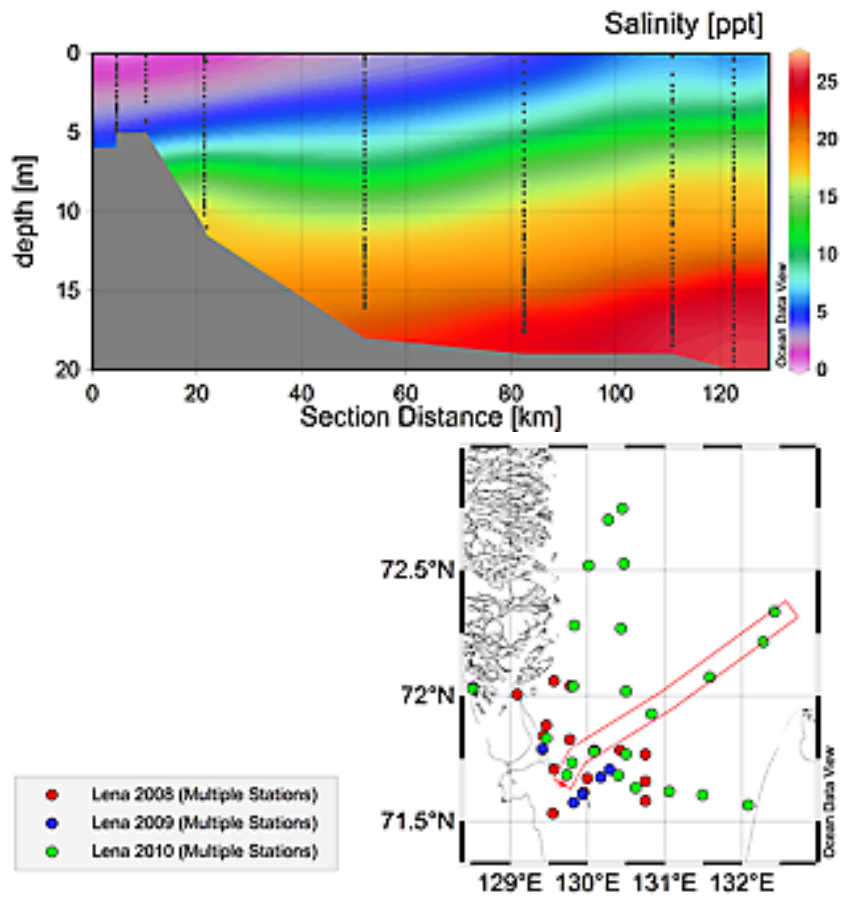

Fig. 2. Salinity for transect 1 in Buor-Khaya Bay in July 2010.

the Bykovskaya Channel. Water with higher salinities had low methane content $(23 \pm 6 \mathrm{nM})$. In 2009, surface values were within the lower (pink) range with $30 \pm 10 \mathrm{nM}$. In 2010, surface values in this area were within the lower (pink) range $(23 \pm 7 \mathrm{nM})$, but also some elevated concentrations were observed $(66 \pm 14 \mathrm{nM})$. For 2009 and 2010, no relation with salinity was obvious.

In 2010 we were able to sample up to $72.5^{\circ} \mathrm{N}$ and to the eastern side of the bay. Methane surface concentrations were mostly low (pink, $<50 \mathrm{nM}$ ), but stations close to the river mouth reached values of approx. $100 \mathrm{nM}$ (Fig. 5).

\subsection{Isotopic signature of methane}

The lightest carbon isotope signature of methane $-42.3 \% \circ \pm 1.7 \%$ o ( $n=3$, Fig. 6) was recorded in the Olenekskaya Channel together with methane concentrations of $414 \pm 52 \mathrm{nM}$. This isotopic signature was comparable to the signature of the creeks draining from permafrost $(-39.4 \% \circ \pm 1.9 \%$ o, $n=3$, Fig. 6); however, here, much higher methane concentrations of $1891 \pm 877 \mathrm{nM}$ were measured. Unfortunately, the isotopic samples from the other Lena channels were lost during transport from the Lena Delta to Germany so that no further information on this topic is available.

In contrast, methane in the Buor-Khaya Bay was much heavier $(-33.6 \% \circ \pm 0.8 \%, n=30$, Fig. 6$)$. The corresponding methane concentrations covered a wide range, from approximately 10 to $100 \mathrm{nM}$. However, at two stations 

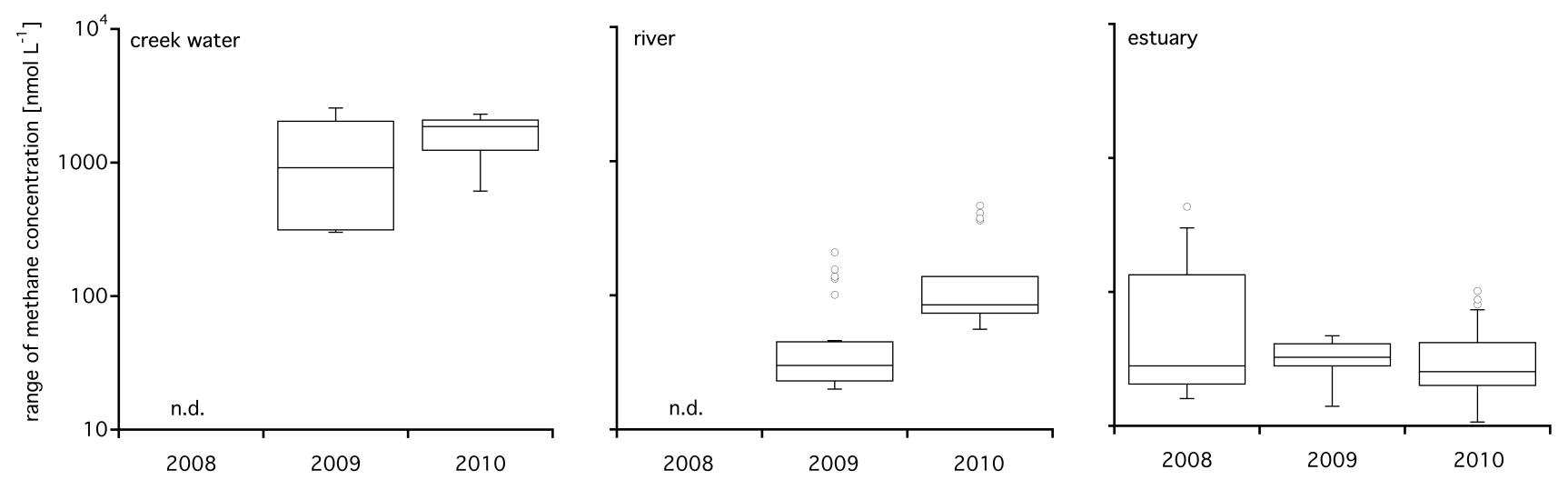

Fig. 3. Range of methane concentrations in creek water, in the Lena River and in the estuary of Buor-Khaya Bay for the years 2008 , 2009 and 2010.

we detected a very heavy signature of $-12.1 \% \circ \pm 2.1 \%$ o ( $n=4$, Fig. 6) together with low methane concentrations $(21 \pm 3 \mathrm{nM})$, which points to a different origin of this methane.

\subsection{Incubation experiments}

Simple incubations of natural river water as well as coastal water revealed no potential of methane consumption. Instead, in river water samples a methane production was observed, despite oxic incubation conditions.

\section{Discussion}

\subsection{Processes within the river}

Methane concentration measurements in the Lena River from 2008 to 2010 revealed average concentrations between 30 and $85 \mathrm{nM}$, which is a bit lower than the concentrations observed in the same area by Semiletov et al. (2011). However, the observed concentrations are within the lower range of boreal rivers for which average concentrations between 10 and $1400 \mathrm{nM}$ have been reported (Middelburg et al., 2002). Isotopic data of methane in creek water and in the Olenekskaya Channel ( -42 and $-39 \%$ ) showed a rather heavy methane signature when compared to other Arctic lakes ( $-58 \%$, Walter et al., 2008) and is much more closer to water samples from polygons at near-by Samoylov Station ( $-45 \%$, Preuss et al., 2013). This unusual signal could indicate that the organic matter used for methane production probably also had a heavy signature. Because extreme cycling of carbon can also lead to rather heavy methane signatures in sediments $(-30 \%$, Binhe et al., 2004). Strong methane oxidation could also shift the signal towards the heavier isotope, but this is not supported by our data.

Within the channels of the Lena River, different processes can alter methane concentrations. High methane concentrations can be due to the input of creek water and other trib- utaries, or by in situ production in sediments or the water column while methane reduction can be due to microbial oxidation and diffusion into the atmosphere.

To assess the microbial aspect of the methane cycle, simple incubation experiments were set up. These experiments revealed no methane consumption at all but a strong methane production. Subsequent experiments for methane oxidation in the lab showed that the detection limit of these experiments was around $20 \mathrm{nM} \mathrm{d}^{-1}$ indicating a rather low methane oxidation potential in the Lena River. Further experiments however have to be done to reveal the reason for this exceptionally low methane oxidation potential.

To calculate the diffusive methane flux, we followed the estimates of Raymond et al. (2012) (see Material and Methods) and calculated a transfer coefficient $k_{600}$ of $1.7 \pm 0.6 \mathrm{~m} \mathrm{~d}^{-1}$ for the Lena River. This value is somewhat lower than values calculated for the Yukon River $\left(3.1 \mathrm{~m} \mathrm{~d}^{-1}\right.$, Striegl et al., 2012) and the Ohio River $\left(5.2 \mathrm{~m} \mathrm{~d}^{-1}\right.$, Beaulieu et al., 2012). Other authors use a different approach for the calculation and sum up the $k_{600}$ calculated with wind speed and $k_{600}$ calculated with water current (Silvennoinen et al., 2008) to a combined $k_{600}$ resulting in a value of $3.1 \mathrm{~m} \mathrm{~d}^{-1}$ in the lower Temmesjoki River (Baltic Sea). Comparisons between wind- and current-based calculations versus flux chamber measurements however show no simple relation between these factors (Beaulieu et al., 2012). Thus we decided to stick to the more conservative assumption of only currentdriven gas transfer.

The Olenekskaya Channel had high methane concentrations and warm water masses and calculated high methane fluxes ( $13 \pm 6 \mathrm{mmol} \mathrm{m}^{-2} \mathrm{~d}^{-1}, n=3$, or $215 \mathrm{mg} \mathrm{C} \mathrm{m}^{-2} \mathrm{~d}^{-1}$ ). Furthermore, in the Olenekskaya Channel, methane ebullition was observed from the sediment, which will additionally increase the total methane flux (Baulch et al., 2011). For the Bykovskaya and Trofimovskaya channels, the flux was $4-5 \mathrm{mmol} \mathrm{m}^{-2} \mathrm{~d}^{-1}$, or $64-81 \mathrm{mg} \mathrm{C} \mathrm{m}^{-2} \mathrm{~d}^{-1}$. Striegl et al. (2012) estimated an areal methane flux 

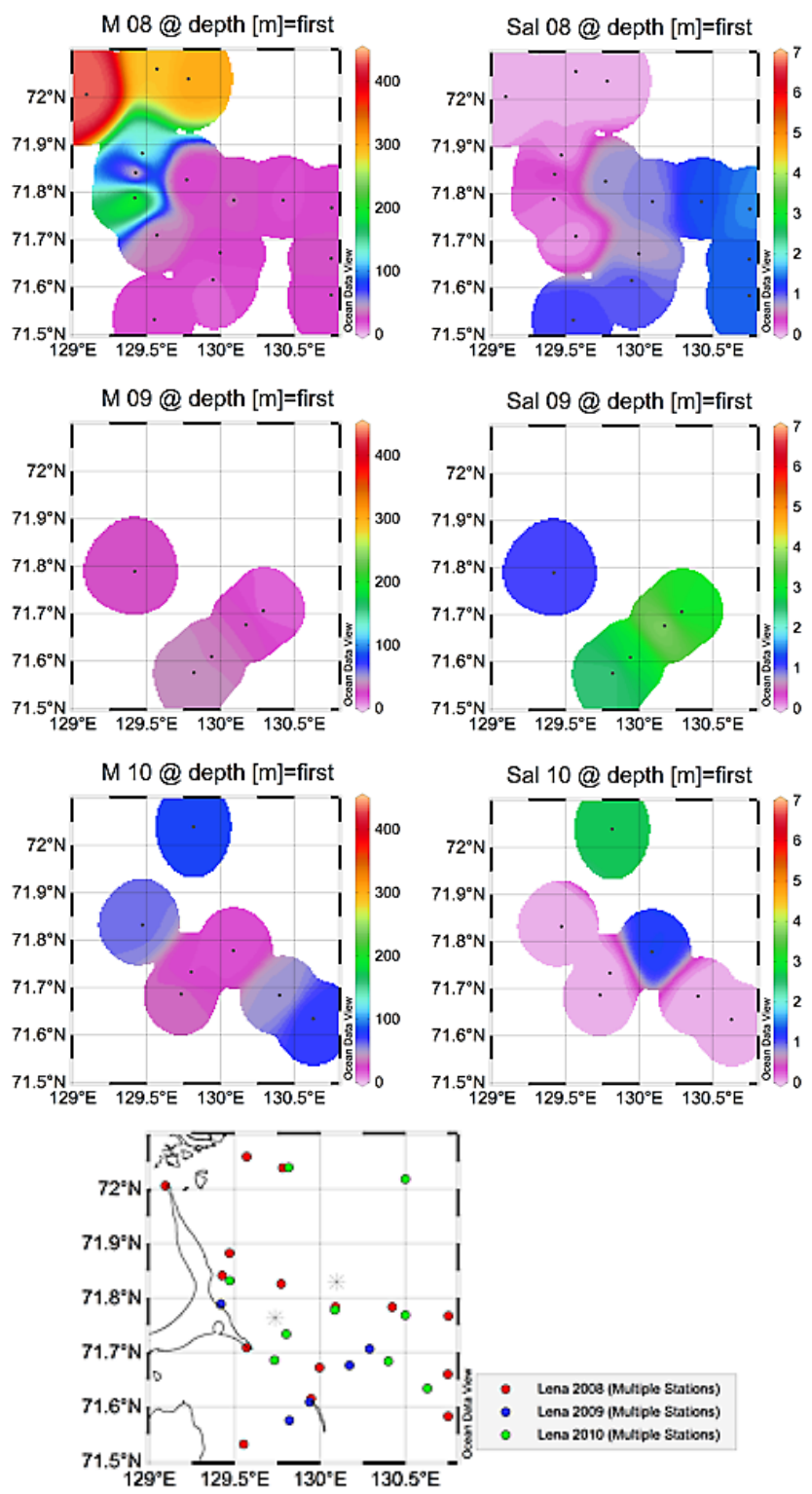

Fig. 4. Surface methane concentrations and salinities in the estuary for the years 2008, 2009 and 2010, within a "common area" as shown in the map inlet.

of $1.4 \mathrm{mmol} \mathrm{m}^{-2} \mathrm{~d}$ for the lower Yukon, and Laurion et al. (2010) showed that permafrost thaw ponds may emit about 0.03 to $5.62 \mathrm{mmol} \mathrm{m}^{-2} \mathrm{~d}^{-1}$ of methane. The methane flux from the Lena River was therefore somewhat higher compared to the Yukon and the thaw ponds.

At the nearby Samoylov research station, the "terrestrial" methane flux ranged from 4 to $28 \mathrm{mg} \mathrm{C} \mathrm{m}^{-2} \mathrm{~d}^{-1}$ at the rim and the depression of polygon structures (Kutzbach et al., 2004). Eddy covariance indicated an average daily methane flux of $19 \mathrm{mg} \mathrm{m}^{-2} \mathrm{~d}^{-1}$ (ranging from $6-22 \mathrm{mg} \mathrm{m}^{-2} \mathrm{~d}^{-1}$ ), mainly determined by wind velocity (Sachs et al., 2008). Thus, the methane flux from the Lena River and its various
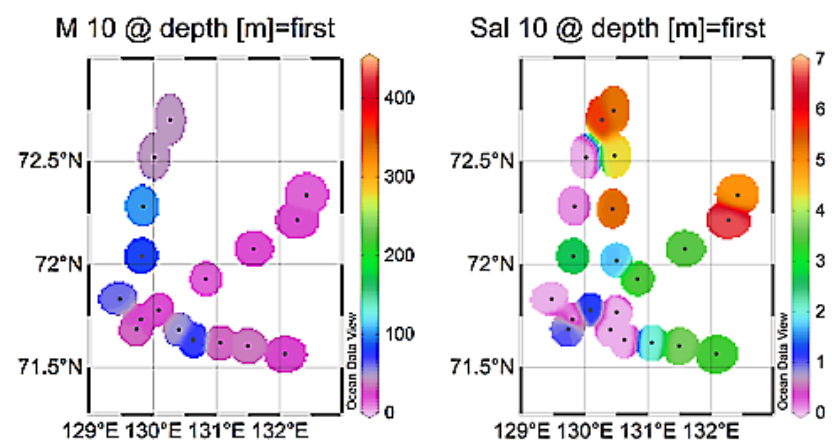

Fig. 5. Surface methane concentrations and salinities in the greater estuary for 2010. For stations see Fig. 1b.

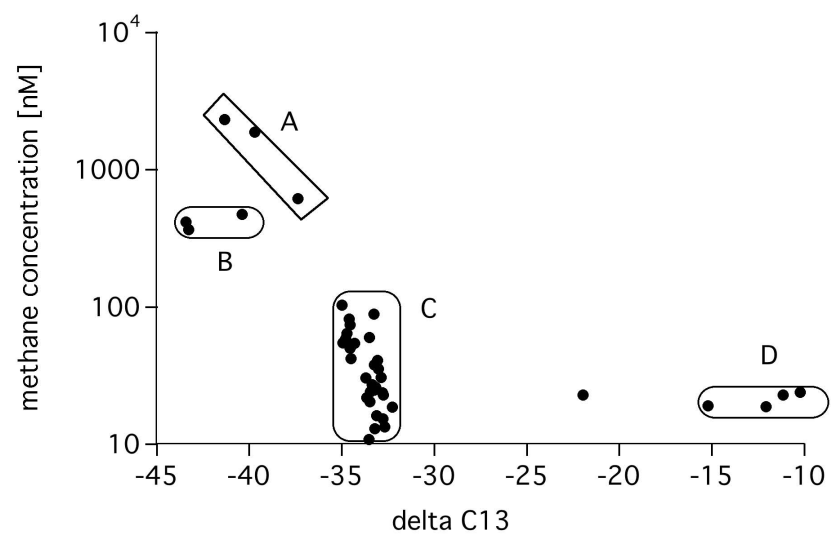

Fig. 6. Carbon isotope signature of methane in 2010, with corresponding methane concentrations in meltwater (A), Olenekskaya Channel (B), Buor-Khaya Bay (C) and two separate stations in Buor-Khaya Bay (D), indicated with an asterisk in Fig. 1.

channels is about $3-10$ times higher than the terrestrial emissions. One reason for the lower terrestrial emission could be that for the terrestrial environment an intense microbial methane oxidation was observed (Preuss et al., 2013; Liebner and Wagner, 2007), which seems to be absent in the river. However, for an assessment of the regional methane fluxes from the whole Lena Delta, it would be important to take into account the different areas of river channels, thaw ponds and terrestrial environment. Additionally, all flux data of the area have to be from the same year and season, but these data are unfortunately not available.

In Fig. 7 the methane concentrations along the river flow are shown. For the Trofimovskaya Channel, there seem to be further sources of methane along its flow, as seen by the increase of methane concentration with flow distance (Fig. 7). However, in the Bykovskaya and Olenekskaya channels, methane concentrations did not change significantly along the flow distances. Based on the work of Anthony et al. (2012) and de Angelis and Scranton (1993), we propose a simple box model to budget the methane fluxes in the Lena. 


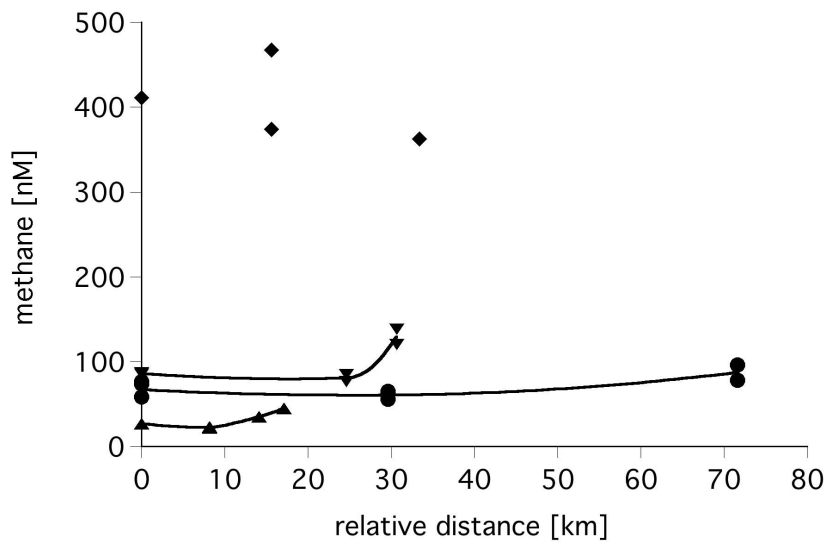

Fig. 7. Methane concentrations in the Olenekskaya Channel 2010 (diamonds), Trofimovskaya Channel 2008 (upward triangle) and 2010 (downward triangle) and the Bykovskaya Channel (circles) plotted versus flow direction and distances from the first station (set as $0 \mathrm{~km}$ ).

For a certain section of the river, the methane flowing out $\left(F_{\text {out }}\right)$ is the sum of the methane flowing into this section $\left(F_{\text {in }}\right)$, the losses due to diffusive flux $\left(F_{\text {diff }}\right)$, the microbial oxidation $\left(F_{\text {oxid }}\right)$ and additional methane supply $\left(F_{\text {supply }}\right)$ from methane production in the river sediment or lateral input from creeks draining into the river.

$F_{\text {out }}=F_{\text {in }}-F_{\text {diffusive }}-F_{\text {oxid }}+F_{\text {supply }}$

The fluxes in and out of a certain river section are calculated by multiplying the measured concentrations with the respective discharge (Anthony et al., 2012). The areal diffusive flux is calculated by multiplying the surface area of this river section (data from Fedorova et al., 2013) with the calculated diffusive flux. The reduction of methane through microbial consumption is assumed to be zero. With these calculations and assumptions, we calculated that, for the two channels Trofimovskaya and Olenekskaya, the methane flux out of the respective channel sections was always bigger than the flux into the sections, even though the loss of methane via diffusion was substantial (Table 1). To maintain the mass balance, the diffusive loss has to be counterbalanced by additional methane sources $\left(F_{\text {supply }}\right)($ Table 1$)$. Such additional sources could be an in situ methane production in the channels or methane coming by small creeks that drain into the river. Unfortunately, no information is available for the in situ methane production rate, and thus we cannot estimate its importance for the methane budget. These creeks have very high methane concentrations, and thus $21-50$ of such creeks would be sufficient to counterbalance the diffusive losses in the respective river sections.

The warmest water temperatures $\left(\mathrm{ca} .15^{\circ} \mathrm{C}\right.$ ) in the Lena over the year are normally recorded in July/August (Yang et al., 2002). As methanogenesis is strongly influenced by temperature (Eugster et al., 2011), highest methane production
Table 1. Methane budget for sections of the Lena River (in $\left.\mathrm{kmold}^{-1}\right)$.

\begin{tabular}{|c|c|c|c|c|c|}
\hline & $F_{\text {out }}$ & $F_{\text {in }}$ & $F_{\text {diffusive }}$ & $F_{\text {supply }}$ & $\begin{array}{l}\text { Number } \\
\text { of creeks } \\
\text { required }\end{array}$ \\
\hline $\begin{array}{l}\text { Trofimovskaya } \\
\text { Channel }^{1}\end{array}$ & 160 & 63 & 199 & 297 & 21 \\
\hline $\begin{array}{l}\text { Olenekskaya } \\
\text { Channel }^{2}\end{array}$ & 53 & 44 & 680 & 689 & 50 \\
\hline $\begin{array}{l}\text { Estimated input } \\
\text { through a creek }\end{array}$ & & & & 14 & \\
\hline
\end{tabular}

${ }^{1}$ Section length $(31 \mathrm{~km})$, width $(1 \mathrm{~km})$ and surface area $\left(39 \mathrm{~km}^{2}\right)$ with data on discharge rates and channel width by Fedorova et al. (2013).

${ }^{2}$ Section length $(33 \mathrm{~km})$, width $(0.5-2.6 \mathrm{~km})$ and surface area $\left(51 \mathrm{~km}^{2}\right)$ with data on discharge rates and channel width by Fedorova et al. (2013).

${ }^{3}$ Estimated input through a creek at Samoylov into the Lena River with a median methane concentration of $1505 \mathrm{nM}$ and a median discharge of $107 \mathrm{~m}^{3} \mathrm{~s}^{-1}$ (Abnizova et al., 2012a, b).

rates will occur in these months. Also soil temperatures and therefore permafrost thawing rates are highest during these months (Boike et al., 2013), which would also increase the discharge of creeks draining from thawing permafrost soil. Thus, the additional supply flux $\left(F_{\text {supply }}\right)$ into the river by in situ methane production or by creeks will be very high in summer, and we assume that our calculated methane flux is in the upper range of the seasonal scale. However, the strength of the methane input following the spring ice melt in the Lena remains uncertain, because under ice cover methane may accumulate for several months and than be released after spring ice melt (Phelps et al., 1998). This has been observed for the Bothnian Bay, where highest methane flux was observed in winter (Silvennoinen et al., 2008).

\subsection{Processes within Buor-Khaya Bay}

When the Lena River enters the coastal area of BuorKhaya Bay, methane concentrations decrease (median concentrations $26-33 \mathrm{nM}, 2008-2010$ ). These concentrations are within the observed range from Shakhova and Semiletov (2007; Semiletov et al., 2011) but lower than methane concentrations reported for other shelf seas, e.g. $290 \mathrm{nM}$ in the North Sea (Grunwald et al., 2007), $57 \mathrm{nM}$ in Barents Sea (Lammers et al., 1995) and 2-240 nM off Spitsbergen (Damm et al., 2005).

The isotopic signature in the estuary (median $-34 \%$ ) is rather heavy, compared to other marine, Arctic values $(-52 \%$, Damm et al., 2005). However, Cramer and Franke (2006) report similar values for the Laptev Sea $(-50$ to $-36 \%$. They assume that this methane is from thermal origin and from marine or terrestrial bedrock. They also report methane escaping from a SW-NE fracture zone in the Laptev Sea. This could also explain the very heavy signature $(-10 \%)$ of the three outliers (Fig. 6) as gas having escaped by the fracture zone. However, as no additional information 
is available on the deuterium signature or the percentage of higher hydrocarbons, and because natural gases contained within and derived from humic sources can be both bacterial and thermogenic depending on the burial history (Whiticar, 1996), a more detailed interpretation of our data is not yet possible.

Within the bay, we have no indications of increasing methane concentrations, and only processes to reduce methane concentrations seem to be relevant.

To determine whether the decrease in methane concentrations observed within Buor-Khaya Bay was due to dilution, the methane data were plotted against salinity (Fig. 8). For the years 2008 and 2010, no correlation was observed between salinity and methane concentration. This was also true when only data with a salinity of $>1$ were used. Additionally, data were classified into different categories of salinity (oligo-, meso- and polyhaline; Caspers, 1959), and the variability of the methane data was correlated to the variability of the salinity data. Also this analysis did not reveal significant results (Kruskal-Wallis rank sum test). Thus, methane loss seems not to be the result of mixing methane-rich river water with methane-poor marine water, as described for other estuaries (de Angelis and Lilley, 1987). This may be due to the very strong stratification of the water column (Fig. 2), as in other river-dominated and stratified estuaries (Middelburg et al., 2002). The hydrographical regimen in the southern Laptev Sea is governed by a high frontal instability and unstable coastal currents (Heim et al., 2013; Charkin et al., 2011). Thus also the methane distribution in the estuary revealed no clear pattern (Fig. 5).

Methane concentration may also be reduced due to microbial oxidation, and can be inferred from isotopic data. In Fig. 9, data from Buor-Khaya Bay are related to the data set with the maximal methane concentration $(102 \mathrm{nM})$; Rayleigh curves are plotted to show how the isotopic signal would change due to microbial oxidation with a fraction factor of 1.017 , or due to diffusion from water into the atmosphere with fractionation factor of 1.0009 (see Material and Methods). As seen in Fig. 9, the observed decrease in methane concentration and the relatively minor shift towards heavier methane cannot be explained by methane oxidation; instead, diffusion seems to be the dominant process here. The lack of methane oxidation is in contrast to other estuaries, where, during summer, oxidation removed a substantial proportion of methane from the freshwater and brackish areas of the estuary (de Angelis and Scranton, 1993). This low methane oxidation potential is also supported by our experiments. One reason could be a pronounced sensitivity of riverine methanotrophic bacteria to increasing salinity (unpublished data).

The diffusive methane flux from the estuary into the atmosphere was also estimated. Based on wind speed data and water characteristics, the methane flux from Buor-Khaya Bay into the atmosphere was calculated (see Material and Methods). The flux of dissolved methane from Buor-Khaya Bay into the atmosphere ranged from 32 to $98 \mu \mathrm{mol} \mathrm{m}^{-2} \mathrm{~d}^{-1}$
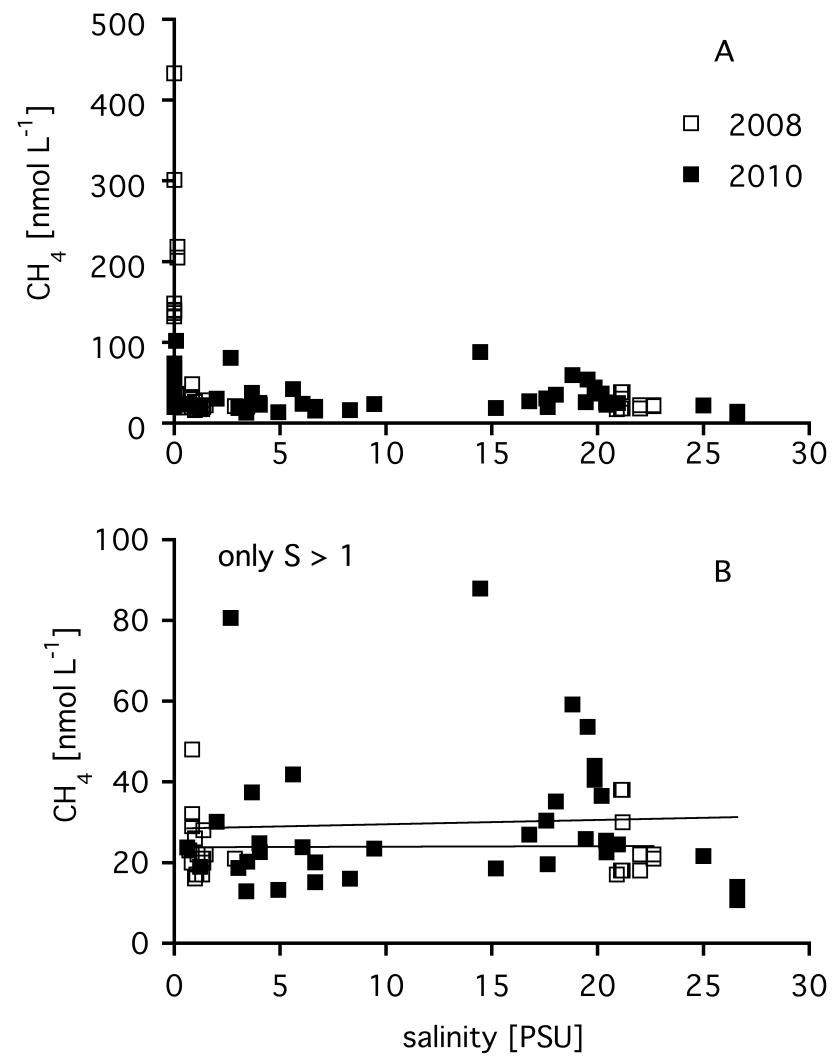

Fig. 8. Methane concentrations versus salinity for 2008 (open squares) and 2010 (closed squares). (A) all samples, (B) only samples with a salinity of $>1$.

along the coast (or $0.52-1.56 \mathrm{mg} \mathrm{C} \mathrm{m}^{-2} \mathrm{~d}^{-1}$ ). These values are about 1000 times smaller than the methane flux from the Lena River. At the northernmost station, the methane flux decreased to $5 \mu \mathrm{mol} \mathrm{m}{ }^{-2} \mathrm{~d}^{-1}$ (or $0.08 \mathrm{mg} \mathrm{C} \mathrm{m}^{-2} \mathrm{~d}^{-1}$ ). This is much lower than the minimum flux of $130 \mu \mathrm{mol} \mathrm{m}^{-2} \mathrm{~d}^{-1}$ previously estimated for European estuaries (Middelburg et al., 2002). Shakhova and Semiletov (2007) reported 3.02$4.86 \mathrm{~g} \mathrm{C} \mathrm{cm}^{-2} \mathrm{~h}^{-1}$ (or $0.07-0.12 \mathrm{mg} \mathrm{C} \mathrm{m}^{-2} \mathrm{~d}^{-1}$ ) methane flux from the East Siberian Sea and northern parts of BuorKhaya Bay in 2003 and 2004. These data correspond well with our northernmost station.

To estimate the riverine input into Buor-Khaya Bay, I estimated the area of direct riverine input with the data of B. Heim (yellow area in Fig. 2, Heim et al., 2013). This area was approximately $130 \mathrm{~km}$ in length and $30 \mathrm{~km}$ in width. Thus, in the respective area in summer 2010, the loss of methane by diffusion can be calculated to about $225 \mathrm{kmold}^{-1}$. The input of the two main channels (Bykovskaya and Trofimovskaya channel with a discharge of 7158 and $15414 \mathrm{~m}^{3} \mathrm{~s}^{-1}$ and 96 and $120 \mathrm{nM}$ of methane) results in a methane input of $219 \mathrm{kmol} \mathrm{d}^{-1}$. Thus the riverine input of methane into the estuary seems to be balanced by the loss through diffusion into the atmosphere. 


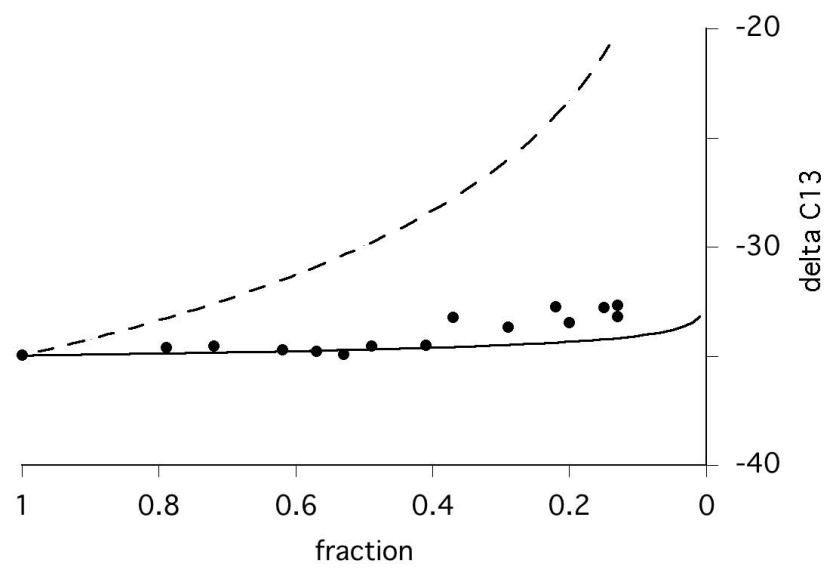

Fig. 9. Fraction of methane oxidised in waters of Buor-Khaya Bay in 2010. The endmember of the Rayleigh curve is based on the data set with the highest methane concentration $(102 \mathrm{nM})$ and the corresponding isotope signature of $-34.96 \%$ VPDB. The curves show the prospective $\delta^{13} \mathrm{C}$ signatures modified by diffusion $(\alpha=1.0009$, solid line) or oxidation ( $\alpha=1.017$, dashed line).

\section{Conclusions}

In the Lena River, methane concentrations showed intermediate concentrations, comparable to boreal estuaries. However, single channels (Olenekskaya Channel) revealed elevated methane concentrations throughout the different years. In the river, microbial methane consumption could not be detected; thus diffusion into the atmosphere must be the dominant process of methane removal. The methane flux from the Lena River and its various channels is 3-10 times higher than the terrestrial emissions. However, to counterbalance this loss and to maintain the observed methane concentrations in the river, additional methane sources are necessary. This additional methane supply could come from small creeks draining from the thawing permafrost soil into the river. They reveal very high methane concentrations, and about 20-50 creeks per $30 \mathrm{~km}$ would be sufficient to maintain the observed methane concentrations. Other sources could be in situ methane production.

When the Lena River enters the estuary, methane concentrations should increase in Buor-Khaya Bay. However, this riverine signal could not be detected in a consistent temporal and spatial pattern. This may be due to the unstable current patterns in the bay. A strong stratification in the bay permitted dilution of the methane-rich water with methane-poor marine water. Again, no significant microbial methane consumption could be detected, and thus methane diffusion is the predominant process of methane loss. A comparison of the riverine methane input and the calculated diffusive loss showed that the riverine input is balanced by the loss through diffusion into the atmosphere.

A rather interesting, heavy isotopic signal for methane $(-34 \%$ ) was observed in the estuary. Thus methane could be of thermogenic origin, but the interaction of natural gases with humic substance from the permafrost makes interpretations of this signal difficult, and further information is needed here.

Acknowledgements. Many thanks are given to the scientific party and the crew of the vessels Puteyski 405 and TB 0012; to B. Heim and K. Carstens for sampling in 2008 and 2009; and E. Damm for assistance in the isotope measurements. I am also grateful for logistical support provided by the Alfred Wegener Institute, in particular by W. Schneider and G. Stoof.

Edited by: P. Overduin

\section{References}

Abnizova, A., Siemens, J., Langer, M., and Boike, J.: Discharge rates for Samoylov Island Flood plain outlet, doi:10.1594/PANGAEA.805251, 2012a.

Abnizova, A., Siemens, J., Langer, M., and Boike, J.: Discharge rates for Samoylov Island Lake outlet, doi:10.1594/PANGAEA.805252, 2012b.

Alin, S. R., de Fátima F. L. Rasera, M., Salimon, C. I., Richey, J. E., Holtgrieve, G. W., Krusche, A. V., and Snidvongs, A.: Physical controls on carbon dioxide transfer velocity and flux in low-gradient river systems and implications for regional carbon budgets, J. Geophys. Res.-Biogeo., 116, G01009, doi:10.1029/2010jg001398, 2011.

Anthony, S. E., Prahl, F. G., and Peterson, T. D.: Methane dynamics in the Willamette River, Oregon, Limnol. Oceanogr., 57, 15171530, doi:10.4319/lo.2012.57.5.1517, 2012.

Bastviken, D., Ejlertsson, J., Sundh, I., and Tranvik, L.: Measurement of methane oxidation in lakes: a comparison of methods, Environ. Sci. Technol., 36, 3354-3361, 2002.

Baulch, H. M., Dillon, P. J., Maranger, R., and Schiff, S. L.: Diffusive and ebullitive transport of methane and nitrous oxide from streams: Are bubble-mediated fluxes important?, J. Geophys. Res.-Biogeo., 116, G04028, doi:10.1029/2011JG001656, 2011.

Beaulieu, J. J., Shuster, W. D., and Rebholz, J. A.: Controls on gas transfer velocities in a large river, J. Geophys. Res.-Biogeo., 117, G02007, doi:10.1029/2011jg001794, 2012.

Binhe, G., Schelske, C., and Hodell, D.: Extreme ${ }^{13} \mathrm{C}$ enrichments in a shallow hypereutrophic lake: Implications for carbon cycling, Limnol. Oceanogr., 49, 1152-1159, 2004.

Boike, J., Abramova, K., Bolshiyanov, D. Y., Grigoriev, M. N., Herzschuh, U., Kattner, G., Knoblauch, C., Kutzbach, L., Mollenhauer, G., and Schneider, W.: Russian-German Cooperation SYSTEM LAPTEV SEA: The Expedition Lena 2009, Reports on Polar and Marine Research, 600, 34 pp., hdl:10013/epic.33540, 2009.

Boike, J., Kattenstroth, B., Abramova, K., Bornemann, N., Chetverova, A., Fedorova, I., Fröb, K., Grigoriev, M., Grüber, M., Kutzbach, L., Langer, M., Minke, M., Muster, S., Piel, K., Pfeiffer, E.-M., Stoof, G., Westermann, S., Wischnewski, K., Wille, C., and Hubberten, H.-W.: Baseline characteristics of climate, permafrost and land cover from a new permafrost observatory in the Lena River Delta, Siberia (1998-2011), Biogeosciences, 10, 2105-2128, doi:10.5194/bg-10-2105-2013, 2013. 
Bussmann, I.: Physical oceanography measured in the Lena Estuary, Sibiria, Russia, in 2010, Alfred Wegener Institute for Polar and Marine Research - Biological Institute Helgoland, Unpublished dataset \#770761, 2011.

Caspers, H.: Vorschläge einer Brackwassernomenklatur (The Venice System), Int. Rev. Ges. Hydrbiol., 44, 313-316, 1959.

Charkin, A. N., Dudarev, O. V., Semiletov, I. P., Kruhmalev, A. V., Vonk, J. E., Sánchez-García, L., Karlsson, E., and Gustafsson, Ö.: Seasonal and interannual variability of sedimentation and organic matter distribution in the Buor-Khaya Gulf: the primary recipient of input from Lena River and coastal erosion in the southeast Laptev Sea, Biogeosciences, 8, 2581-2594, doi:10.5194/bg8-2581-2011, 2011.

Cramer, B. and Franke, D.: Indication for an active petroluem system in the Laptev Sea, NE Siberia, J. Petrol. Geol., 28, 369-384, doi:10.1111/j.1747-5457.2005.tb00088.x, 2006.

Damm, E., Mackensen, A., Budéus, G., Faber, E., and Hanfland, C.: Pathways of methane in seawater: Plume spreading in an Arctic shelf environment (SW-Spitsbergen), Cont. Shelf Res., 25, 14531472, 2005.

Damm, E., Schauer, U., Rudels, B., and Haas, C.: Excess of bottomreleased methane in an Arctic shelf sea polynya in winter, Cont. Shelf Res., 27, 1692-1701, doi:10.1016/j.csr.2007.02.003, 2007.

de Angelis, M. A. and Lilley, M. D.: Methane in surface waters of Oregon estuaries and rivers, Limnol. Oceanogr., 32, 716-722, 1987.

de Angelis, M. A. and Scranton, M. I.: Fate of methane in the Hudson River and estuary, Global Biogeochem. Cy., 7, 509-523, 1993.

Dittmar, T. and Kattner, G.: Recalcitrant dissolved organic matter in the ocean: major contribution of small amphiphilics, Mar. Chem., $82,115-123,2003$.

Eugster, W., DelSontro, T., and Sobek, S.: Eddy covariance flux measurements confirm extreme $\mathrm{CH}_{4}$ emissions from a Swiss hydropower reservoir and resolve their short-term variability, Biogeosciences, 8, 2815-2831, doi:10.5194/bg-8-2815-2011, 2011.

Fedorova, I., Bolshiyanov, Yu, D., Chetverova, A., Makarov, A., and Tretiyakov, M.: Measured water discharges, suspended supply and morphometric parameters of cross-sections in the Lena River Delta during summer period 2002-2012, doi:10.1594/PANGAEA.808854, 2013.

Fisher, R. E., Sriskantharajah, S., Lowry, D., Lanoiselle, M., Fowler, C. M. R., James, R. H., Hermansen, O., Myhre, C. L., Stohl, A., Greinert, J., Nisbet-Jones, P. B. R., Mienert, J., and Nisbet, E. G.: Arctic methane sources: Isotopic evidence for atmospheric inputs, Geophys. Res. Lett., 38, 6, L21803, doi:10.1029/2011g1049319, 2011.

Frey, K. E. and McClelland, J. W.: Impacts of permafrost degradation on arctic river biogeochemistry, Hydrol. Process., 23, 169182, doi:10.1002/hyp.7196, 2009.

Grunwald, M., Dellwig, O., Liebezeit, G., Schnetger, B., Reuter, R., and Brumsack, H.-J. r.: A novel time-series station in the Wadden Sea (NW Germany): First results on continuous nutrient and methane measurements, Mar. Chem., 107, 411-421, 2007.

Happell, J. D., Chanton, J. P., and Showers, W. J.: Methane transfer across the water-air interface in stagnant wooded swamps of Florida: Evaluation of mass-transfer coefficients and isotopic fractionation, Limnol. Oceanogr., 40, 290-298, 1995.
Heim, B., Abramova, E., Doerffer, R., Günther, F., Hölemann, J., Kraberg, A., Lantuit, H., Loginova, A., Martynov, F., Overduin, P. P., and Wegner, C.: Ocean Colour remote sensing in the Southern Laptev Sea: evaluation and applications, Biogeosciences Discuss., 10, 3849-3889, doi:10.5194/bgd-10-3849-2013, 2013.

Holmes, R. M., McClelland, J. W., Peterson, B. J., Tank, S. E., Bulygina, E., Eglinton, T. I., Gordeev, V. V., Gurtovaya, T. Y., Raymond, P. A., and Repeta, D. J.: Seasonal and annual fluxes of nutrients and organic matter from large rivers to the Arctic Ocean and surrounding seas, Estuar. Coast., 35, 369-382, 2012.

IPCC: Denman, K. L., Brasseur, G., Chidthaisong, A., Ciais, P., Cox, P. M., Dickinson, R. E., Hauglustaine, D., Heinze, C., Holland, E., Jacob, D., Lohmann, U., Ramachandran, S., Dias, P. L. d. S., Wofsy, S. C., and Zhang, X.: Couplings between changes in the climate system and biogeochemistry, in: Climate Change 2007: The Physical Science Basis. Contribution of Working Group I to the Fourth Assessment Report of the Intergovernmental Panel on Climate Change, 2007.

Kutzbach, L., Wagner, D., and Pfeiffer, E.-M.: Effect of microrelief and vegetation on methane emission from wet polygonal tundra, Lena Delta, Northern Siberia, Biogeochemistry, 69, 341-362, 2004.

Lammers, R. B., Shiklomanov, A. I., Vörösmarty, C. J., Fekete, B. M., and Peterson, B. J.: Assessment of contemporary Arctic river runoff based on observational discharge records, J. Geophys. Res., 106, 3321-3334, 2001.

Lammers, S., Suess, E., and Hovland, M.: A large methane plume east of Bear Island (Barents Sea): Implications for the marine methane cycle, Geologische Rundschau, 84, 59-66, 1995.

Lantuit, H., Atkinson, D., Overduin, P. P., Grigoriev, M., Rachold, V., Grosse, G., and Hubberten, H.-W.: Coastal erosion dynamics on the permafrost-dominated Bykovsky Peninsula, north Siberia, 1951-2006, Polar Res., 30, 7341, doi:10.3402/polar.v30i0.7341, 2011.

Laurion, I., Vincent, W. F., MacIntyre, S., Retamal, L., Dupont, C., Francus, P., and Pienitz, R.: Variability in greenhouse gas emissions from permafrost thaw ponds, Limnol. Oceanogr., 55, 115133, doi:10.4319/lo.2010.55.1.0115, 2010.

Liebner, S. and Wagner, D.: Abundance, distribution and potential activity of methane oxidizing bacteria in permafrost soils from the Lena Delta, Siberia, Environ. Microbiol., 9, 107-117, 2007.

McClelland, J. W., Dery, S. J., Peterson, B. J., Holmes, R. M., and Wood, E. F.: A pan-arctic evaluation of changes in river discharge during the latter half of the 20th century, Geophys. Res. Lett, 33, L06715, doi:10.1029/2006GL025753, 2006.

McClelland, J. W., Holmes, R. M., Dunton, K. H., and Macdonald, R. W.: The Arctic Ocean Estuary, Estuar. Coast., 35, 353-368, doi:10.1007/s12237-010-9357-3, 2012.

McGuire, A. D., Anderson, L. G., Christensen, T. R., Dallimore, S., Guo;, L., Hayes, D. Y., Heimann, M., Lorenson, T. D., MacDonald, R. W., and Roulet, N.: Sensitivity of the carbon cycle in the Arctic to climate change, Ecol. Monogr., 79, 523-533, 2009.

Middelburg, J. J., Nieuwenhuize, J., Iversen, N., Hogh, N., H. deWilde, Helder, W., Seifert, R., and Christof, O.: Methane distribution in European tidal estuaries, Biogeochemistry, 59, 95119, 2002.

Peterson, B. J., Holmes, R. M., McClelland, J. W., Vörösmarty, C. J., Lammers, R. B., Shiklomanov, A. I., Shiklomanov, I. A., and Rahmstorf, S.: Increasing river discharge to the Arctic Ocean, 
Science, 298, 2171-2173, doi:10.1126/science.1077445, 2002.

Phelps, A. R., Peterson, K. M., and Jeffries, M. O.: Methane efflux from high-latitude lakes during spring ice melt, J. Geophys. Res., 103, 29029-29036, 1998.

Preuss, I., Knoblauch, C., Gebert, J., and Pfeiffer, E.-M.: Improved quantification of microbial $\mathrm{CH}_{4}$ oxidation efficiency in arctic wetland soils using carbon isotope fractionation, Biogeosciences, 10, 2539-2552, doi:10.5194/bg-10-2539-2013, 2013.

Raymond, P. A., Zappa, C. J., Butman, D., Bott, T. L., Potter, J., Mulholland, P., Laursen, A. E., McDowell, W. H., and Newbold, D.: Scaling the gas transfer velocity and hydraulic geometry in streams and small rivers, Limnol. Oceanogr., 2, 41-53, doi:10.1215/21573689-1597669, 2012.

Sachs, T., Wille, C., Boike, J., and Kutzbach, L.: Environmental controls on ecosystem-scale $\mathrm{CH}_{4}$ emission from polygonal tundra in the Lena River Delta, Siberia, J. Geophys. Res., 113, G00A03, doi:10.1029/2007JG000505, 2008.

Semiletov, I. P., Pipko, I. I., Shakhova, N. E., Dudarev, O. V., Pugach, S. P., Charkin, A. N., McRoy, C. P., Kosmach, D., and Gustafsson, Ö.: Carbon transport by the Lena River from its headwaters to the Arctic Ocean, with emphasis on fluvial input of terrestrial particulate organic carbon vs. carbon transport by coastal erosion, Biogeosciences, 8, 2407-2426, doi:10.5194/bg8-2407-2011, 2011.

Semiletov, I. P., Shakhova, N. E., Pipko, I. I., Pugach, S. P., Charkin, A. N., Dudarev, O. V., Kosmach, D. A., and Nishino, S.: Spacetime dynamics of carbon stocks and environmental parameters related to carbon dioxide emissions in the Buor-Khaya Bay of the Laptev Sea, Biogeosciences Discuss., 10, 2159-2204, doi:10.5194/bgd-10-2159-2013, 2013.

Shakhova, N. and Semiletov, I.: Methane release and coastal environment in the East Siberian Arctic shelf, J. Mar. Syst., 66, 227-243, 2007.

Shakhova, N., Semiletov, I., and Panteleev, G.: The distribution of methane on the Siberian Arctic shelves: Implications for the marine methane cycle, Geophys. Res. Lett., 32, L09601, doi:10.1029/2005g1022751, 2005.

Shakhova, N., Semiletov, I., Salyu, A., Yusupov, V., Kosmach, D., and Gustafsson, Ö.: Extensive methane venting to the atmosphere from sediments of the East Siberian Arctic Shelf, Science, 327, 1246, doi:10.1126/science.1182221, 2010.

Silvennoinen, H., Liikanen, A., Rintala, J., and Martikainen, P.: Greenhouse gas fluxes from the eutrophic Temmesjoki River and its Estuary in the Liminganlahti Bay (the Baltic Sea), Biogeochemistry, 90, 193-208, doi:10.1007/s10533-008-9244-1, 2008.
Striegl, R. G., Dornblaser, M. M., McDonald, C. P., Rover, J. R., and Stets, E. G.: Carbon dioxide and methane emissions from the Yukon River system, Global Biogeochem. Cy., 26, GB0E05, doi:10.1029/2012GB004306, 2012.

Symon, C., Arris, L., Heal, B., and Symon, C.: Arctic Climate Impact Assessment - Scientific Report, Cambridge University Press, Cambrigde, 1046 pp., 2005.

Syvitski, J. P. M. and Saito, Y.: Morphodynamics of deltas under the influence of humans, Global Planet. Change, 57, 261-282, doi:10.1016/j.gloplacha.2006.12.001, 2007.

Tank, S. E., Raymond, P. A., Striegl, R. G., McClelland, J. W., Holmes, R. M., Fiske, G. J., and Peterson, B. J.: A land-to-ocean perspective on the magnitude, source and implication of DIC flux from major Arctic rivers to the Arctic Ocean, Global Biogeochem. Cy., 26, Gb4018, doi:10.1029/2011gb004192, 2013.

Walter, K. M., Chanton, J. P., III, F. S. C., Schuur, E. A. G., and Zimov, S. A.: Methane production and bubble emissions from arctic lakes: Isotopic implications for source pathways and ages, J. Geophys. Res., 113, G00A08, doi:10.1029/2007JG000569, 2008.

Wanninkhof, R.: Relationship between wind speed and gas exchange over the ocean, J. Geophys. Res., 97, 7373-7382, 1992.

Wanninkhof, R., Asher, W. E., Ho, D. T., Sweeney, C. S., and McGillis, W. R.: Advances in quantifying air-sea gas exchange and environmental forcing, Annu. Rev. Mar. Sci., 1, 213-244, doi:10.1146/annurev.marine.010908.163742, 2009.

Wegner, C., Bauch, D., Hölemann, J. A., Janout, M. A., Heim, B., Novikhin, A., Kassens, H., and Timokhov, L.: Interannual variability of surface and bottom sediment transport on the Laptev Sea shelf during summer, Biogeosciences, 10, 11171129, doi:10.5194/bg-10-1117-2013, 2013.

Wetterich, S., Overduin, P. P., and Grigoriev, M.: Russian-German Cooperation SYSTEM LAPTEV SEA: The expedition Eastern Laptev Sea - Buor Khaya Peninsula 2010, Reports on Polar and Marine Research, 629, 101 pp., hdl:10013/epic.37743, 2011.

Whiticar, M. J.: Stable isotope geochemistry of coals, humic kerogens and related natural gases, Int. J. Coal Geol., 32, 191-215, 1996.

Wiesenburg, D. A. and Guinasso, N. L.: Equilibrium solubilities of methane, carbon monoxide and hydrogen in water and sea water, J. Chem. Eng. Data, 24, 356-360, 1979.

Yang, D., Kane, D. L., Hinzman, L. D., Zhang, X., Zhang, T., and Ye, H.: Siberian Lena River hydrologic regime and recent change, J. Geophys. Res., 107, 4694, doi:10.1029/2002jd002542, 2002 